\title{
Gender analysis in resource utilization among homestead vegetable growers
}

\author{
Vani Chandran* and Bindu Podikunju ${ }^{1}$ \\ Department of Agricultural Extension, College of Agriculture (KAU), Vellayani, Thiruvananthapuram \\ (Kerala) India (Email: vaniagri93@gmail.com)
}

\begin{abstract}
Agriculture plays a significant role in the growth and development of the nation. Agriculture productivity is happened only when correct combination of various resources combines. So that access to resources is often claimed to be essential for improving agricultural productivity. But many of the farmers lack access to various agricultural resources on time, especially women. They are often claimed to have less access to resources in comparison to men. This undermines their chances of entering in to agricultural sectors. Hence, the present study was conducted to analyze the gender role in resource utilization. The study was conducted in 120 homesteads of Kollam district. From the result we can conclude that access and control of various agriculture related resource is more men dominated, it does not mean that such resources were not available for use of women instead it meant that for the use and control of such resources women required assistance or permission of their spouse.
\end{abstract}

Key Words : Gender roles, Resource utilization, Homestead vegetable production, Access to resources, Control of resources

View Point Article : Chandran, Vani and Podikunju, Bindu (2019). Gender analysis in resource utilization among homestead vegetable growers. Internat.J.agric.Sci., 15 (2) : 260-262, DOI:10.15740/HAS/IJAS/15.2/260-262. Copyright@2019: Hind Agri-Horticultural Society.

Article History : Received : 29.03.2019; Revised : 07.05.2019; Accepted : 14.05.2019

*Author for correspondence:

${ }^{1}$ Krishi Vigyan Kendra (KAU), Sadanandapuram, Kollam (Kerala) India 